\title{
Assessment of knowledge and attitude of allied healthcare professionals about COVID-19 across Saudi Arabia
}

\author{
Deepti Shrivastava $^{\mathrm{a}, *}$, Abdulrahman A. Alduraywish ${ }^{\mathrm{b}}$, Kumar Chandan Srivastava $^{\mathrm{c}}$, \\ Abdalkarem F. Alsharari ${ }^{\mathrm{d}}$, Khalid Al-Johani ${ }^{\mathrm{e}}$, Mohammed G. Sghaireen ${ }^{\mathrm{f}}$ \\ and Mohammad Khursheed Alam ${ }^{\mathrm{g}}$ \\ ${ }^{a}$ Periodontics, Preventive Dentistry, College of Dentistry, Jouf University, Sakaka, Saudi Arabia \\ ${ }^{\mathrm{b}}$ Internal Medicine Department, Medical College, Jouf University, Sakaka, Saudi Arabia \\ ' Oral Medicine \& Radiology, Oral and Maxillofacial Surgery \& Diagnostic Sciences, College of Dentistry, Jouf \\ University, Sakaka, Saudi Arabia \\ ${ }^{\mathrm{d}}$ Nursing Department, College of Applied Medical Sciences, Jouf University, Sakaka, Saudi Arabia \\ ${ }^{\mathrm{e}}$ Department of Oral Diagnostic Sciences, Faculty of Dentistry, King Abdulaziz University, Saudi Arabia \\ ${ }^{\mathrm{f}}$ Prosthodontics, Prosthetic Dental Sciences, College of Dentistry, Jouf University, Sakaka, Saudi Arabia \\ g Orthodontics, Department of Preventive Dentistry, College of Dentistry, Jouf University, Sakaka, Saudi Arabia
}

Received 8 September 2020

Accepted 12 October 2020

\begin{abstract}
.
BACKGROUND: The coronavirus disease (COVID-19) has shown a catastrophic effect on mankind. The allied healthcare professionals (AHPs) play a pivotal role against COVID-19.

OBJECTIVE: To appraise the knowledge and attitude about COVID-19 of AHPs working across Saudi Arabia.

METHODS: This cross-sectional study was conducted using Qualtrics software to gather data from all five regions of Saudi Arabia during the nationwide lockdown in April 2020. Complete responses of 195 AHPs were considered for analysis. The questionnaire consisted of 15 and 14 questions on knowledge and attitude, respectively. The overall scores of each domain were calculated and modified Bloom's criterion was applied to categorize them into a three-point ordinal scale. Statistical analysis was performed using Chi-square test along with multivariate logistic regression for significant parameters.

RESULTS: The AHPs displayed a moderate level of knowledge (58.2\%) and a good level of attitude (80\%). The AHPs were found to have a non-significant $(P>0.05)$ difference in the level of knowledge within age, gender, region, occupation, educational level, organizational setup and years of experience. The attitude of AHPs working in a private setup has shown a 2.8 times $(P=0.020)$ higher risk for having moderate/poor attitude compared to the AHPs working in a government organization.

CONCLUSION: AHPs displayed a moderate level of knowledge and good attitude towards COVID-19. Emphasis should be given to continuous professional development in order to enhance their knowledge. Furthermore, strategies should be developed in the private sector to positively reinforce the attitude of AHPs.
\end{abstract}

Keywords: Pandemic, health services research, SARS CoV-2, infection control, coronavirus

*Address for correspondence: Dr. Deepti Shrivastava, Periodontics, Preventive Dentistry, College of Dentistry, Jouf University, Sakakah - Al Jouf Province, 72345, Saudi Arabia. Tel.: +966 5007 82498; E-mail: sdeepti20@gmail.com.

\section{Introduction}

Since the inception of the coronavirus disease (COVID-19) in December 2019 [1], healthcare workers (HCWs) are constantly providing services to the 
diseased individuals. For a system to function efficiently, it needs support of people who are working at the background or providing assistance to the health care professionals (HCPs) [2,3]. For any nation, the allied health care professionals (AHPs) are an indispensable component in the Health care delivery system. They continued to act as a backbone in the present pandemic situation by providing constant support to the frontline HCPs. AHPs play role in disease identification, evaluating the parameters which assist in obtaining a diagnosis and providing rehabilitation services $[4,5]$. Broadly speaking they are non-nurse, non-physician health care providers, including physical therapists, occupational therapists, nutritionists, dieticians, speech pathologists, dental technicians, dental assistants, diagnostic medical personnel, imaging specialists, physician assistants, and many more [4]. Any disparity in coordination while following the protocols and recommendations between the HCPs and AHPs can result in severe consequences [6]. With the constant rise in COVID19 cases, the AHPs are stressed and show signs of burnout, because of the overload and fear of the unknown [7]. In this difficult time, they have to provide care to the patients by keeping themselves safe.

COVID-19 has been declared a pandemic on 11 march 2020 by the World Health Organization (WHO) [8]. It is believed to be caused by severe acute respiratory syndrome corona virus-2 (SARS COV-2) [9]. The disease can be asymptomatic in its initial phase to symptoms ranging from fever, dry cough, shortness of breath, headache, diarrhoea and vomiting $[9,10]$. Furthermore, an alteration or loss in taste sensation and perception of smell has been recognized as a common clinical presentation [11]. COVID-19 has the potential of being transmitted from one person to another through direct or contact transmission [10]. The other routes of transmission can be fecal-oral, saliva and aerosol. In case of indirect transmission, it occurs via airborne and fomite $[12,13]$. It is believed to be transmitted via inanimate objects as the virus can stay alive on these objects from hours to days [14]. Although the case fatality rate is $3.4 \%$, which is comparatively less than past epidemics such as the severe acute respiratory syndrome coronavirus (SARS-CoV) and Middle East respiratory syndrome coronavirus (MERS-CoV), it has claimed more lives all around the world [15].

Saudi Arabia (KSA) had witnessed an epidemic of MERS-CoV in 2012 and subsequently government had made policies and procedure to combat the disease [16]. Similarly, in the early days of COVID-19, advisories and guidelines were issued to counteract this pandemic situation [17-19]. Globally, AHPs such as diagnostic personal at screening or imaging specialist who are processing the radiographs and dental technicians are working at the same pace with the HCPs or dental health care professionals (DH CPs). Nonetheless, the role of other AHPs such as nutritionists and dieticians during and post COVID19 in providing counselling to the diseased individuals are noteworthy [20]. In the present COVID19 era, it is important to assess the knowledge and attitude of the health services provided by the allied healthcare professionals (AHPs) as they play a pivotal role against COVID-19 along with other healthcare workers. To the best of our knowledge, none of the research papers have exclusively assessed the knowledge and attitude of AHPs about COVID-19. Thus, the aim of the study was to assess the knowledge and attitude of AHPs towards COVID-19 across KSA.

\section{Materials and methods}

\subsection{Study population}

A cross-sectional study was conducted in the month of April 2020 across KSA with the help of a Qualtrics online survey tool. The study was approved by the local ethical board of Jouf University (1407/21). Out of 236 questionnaires only 195 were considered for analysis. Forty-one responses were not included in the study as it was incompletely filled; hence the response rate was calculated as $82.6 \%$.

\subsection{Data collection}

The questionnaire was prepared by modifying the questions taken from studies done to assess the knowledge, attitude, and practice (KAP) about COVID-19 on a Chinese resident [21] and KAP about MERS$\mathrm{CoV}$ [22] as well as adopting the recommendations of Meng et al. [10]. The questionnaire was prepared in two languages (Arabic and English) as per the need of the native speakers and international communities. It was forward and backward translated by two professional bilingual translators with an internal consistency coefficient of 0.83 , showing a perfect agreement (English to Arabic and Arabic to English). To carry out this process a committee was formed which had scrutinized the procedure at every step. The initial questionnaire was distributed to 10 participants to check its test-retest reliability and obtained 
a score of 0.80 , indicating a good reliability. These responses were not included in the final study sample. As per the result of pilot study the final questionnaire was prepared for survey. The questionnaire consisted of three segments namely demographic data, knowledge domain and attitude domain. There were 15 questions in the knowledge domain and 14 questions in the attitude domain, where all questions were closed ended. The knowledge domain questions were assessed with three given options as "Yes", "No" and "I don't know". Whereas, the attitude domain questions were assessed on a 5-point Likert's scale from "strongly agree" to "strongly disagree". Participants were given a choice to voluntarily participate in the study and their identity was kept anonymous.

\subsection{Data analysis}

In the knowledge domain for every correct answer a count of "1" was given whereas the wrong answer received " 0 ". Here, the least possible score was " 0 " and the maximum attainable score was " 15 ". Similarly, in the attitude domain the "strongly agree" response received a tally of " 5 " and subsequently the "strongly disagree" the code was "1". For the negatively worded questions, codes were flipped in both the domains. For this domain the lowest obtainable score was " 14 " and the maximal achievable score was "70".

Later, the score obtained from each question were added to calculate the gross score of each domain for every respondent. Finally, the modified bloom's cut-off was used to create three-point ordinal scales of the gross score of each domain [23]. Accordingly, the knowledge domain was categorized as good $(\geq 80 \%$ total score i.e.12-15), moderate $(60 \%-79 \%$ total score i.e.9-11) and poor knowledge ( $<60 \%$ total score i.e. $\leq 8)$. Likewise, attitude domain had categories as good $(\geq 80 \%$ total score i.e. 56-70), moderate $(60 \%-79 \%$ total score i.e.42-55) and poor attitude $(<60 \%$ total score i.e. $\leq 41)$. The data was analyzed via using SPSS software version 21. For univariate analysis, chi-square test was used and multivariate logistic regression was employed for variable showed significant results in previous analysis.

\section{Results}

A total of 195 respondents participated in the study, of which $68.7 \%$ were male and $31.3 \%$ were female.
About half $(50.3 \%)$ of the respondents were in the age group of 31-40 years. The maximum responses for the survey were gathered from the northern region (34.9\%) whereas the eastern region of KSA $(5.1 \%)$ contributed the least. The majority of our respondents had a bachelor's degree (47.2\%) and AHPs with more than 10 years of experience constituted maximum $(35.4 \%)$ in the sample. AHPs working in the governmental sector represented in high number $(84.6 \%)$ compared to their private contemporaries. Considering the nature of work set-up, AHPs engaged in regional hospitals $(52.8 \%)$ outscored their counterparts by participating in large numbers. On comparing the preferred source of information, the Ministry of Health $(\mathrm{MOH})$ website was found to be trending compared to the other sources (Table 1).

The assessment of knowledge domain was done with 15 questions. More than half of the respondents (52.8\%) displayed a moderate level of knowledge, whereas about $32.8 \%$ showed good knowledge. Majority of respondents gave an incorrect response for two questions which dealt with nomenclature $(63.07 \%)$ and regulation regarding hand hygiene $(91.8 \%)$. For the remaining questions, they responded well with outstanding response for question related to disease transmission (97.4\%) and presenting symptoms (99\%) (Table 2).

For evaluating the attitude domain, 14 questions were asked from the AHPs. The majority (80\%) showed good attitude whereas only $2.1 \%$ had poor attitude. A large part of the questions were answered correctly and a phenomenal response were observed for question referring to the identification of precipitating factors (Strongly agree $-82.6 \%$ ) and PPEs (Strongly agree $-81.5 \%$ ). The negatively worded questions were answered incorrectly (Table 3 ).

With regards to the knowledge domain, except source of information $(P<0.001)$, no other independent factors were found to have significant association. For the sake of better statistical interpretation, the moderate and poor levels of attitude scores were combined resulting in overall attitude score into dichotomous variable. AHPs working in governmental organization were found to have significantly $(P<0.05)$ higher than then their contemporary working in a private setup (Table 4).

Significant results of univariate analysis for attitude domain were subjected to multivariate logistic regression. The AHPs working in private organization displayed a 2.8 times hgher risk of having moderate/poor attitude in reference to employees of a governmental organization (Table 5). 
Table 1

Sample characteristics

\begin{tabular}{|c|c|c|}
\hline Variable & Responses & $f(\%)$ \\
\hline Sample size (n) & 195 & \\
\hline \multicolumn{3}{|l|}{$\begin{array}{l}\text { Demographic and } \\
\text { biographic data }\end{array}$} \\
\hline \multirow{4}{*}{ Age } & $20-30$ years & $57(29.2)$ \\
\hline & $31-40$ years & $98(50.3)$ \\
\hline & $41-50$ years & $32(16.4)$ \\
\hline & $\geq 51$ years & $8(4.1)$ \\
\hline \multirow{2}{*}{ Gender } & Male & $134(68.7)$ \\
\hline & Female & $61(31.3)$ \\
\hline \multirow[t]{2}{*}{ Nationality } & Saudi & $151(77.4)$ \\
\hline & Non-Saudi & $44(22.6)$ \\
\hline \multirow[t]{5}{*}{ Region of Saudi Arabia } & Central region (Riyadh, Qassim) & $40(20.5)$ \\
\hline & Eastern region (Dammam, Jubail, Hassa and others) & $10(5.1)$ \\
\hline & Western region (Makkah, Jeddah,Taif and Madinah) & $42(21.5)$ \\
\hline & Northern region (Hail, Aljouf, Tabouk andArar) & $68(34.9)$ \\
\hline & Southern region (Assir, Jazan, Najran, Baha) & $35(17.9)$ \\
\hline \multicolumn{3}{|c|}{ Education and work-related data } \\
\hline \multirow[t]{5}{*}{ Educational level } & Intern & $17(8.7)$ \\
\hline & Diploma degree/Associate college & $34(17.4)$ \\
\hline & Bachelor's degree & $92(47.2)$ \\
\hline & Master's degree & $34(17.4)$ \\
\hline & Doctorate/PhD & $18(9.2)$ \\
\hline \multirow[t]{4}{*}{ Work experience } & $1-3$ years & $58(29.7)$ \\
\hline & $4-6$ years & $34(17.4)$ \\
\hline & $7-10$ years & $34(17.4)$ \\
\hline & More than 10 years & $69(35.4)$ \\
\hline \multirow[t]{2}{*}{ Nature of organization } & Government & $165(84.6)$ \\
\hline & Private & $30(15.4)$ \\
\hline \multirow[t]{9}{*}{ Type of work setup } & Non-academic & \\
\hline & Private clinic & $8(4.1)$ \\
\hline & Primary healthcare center & $14(7.2)$ \\
\hline & Regional/Public hospital & $103(52.8)$ \\
\hline & Specialized hospital/Referral center & $7(3.6)$ \\
\hline & Private hospital or medical complex & $17(8.7)$ \\
\hline & Military hospital/Medical Clinic & $36(18.5)$ \\
\hline & Academic & \\
\hline & University hospital/Clinic & $10(5.1)$ \\
\hline \multirow[t]{4}{*}{ Source of information $€$} & Social media & $94(48.2)$ \\
\hline & Professional colleague & $25(12.8)$ \\
\hline & Ministry of Health website & $157(80.5)$ \\
\hline & Journals & $47(24.1)$ \\
\hline
\end{tabular}

Note: $€$ responses are not mutually exclusive.

\section{Discussion}

Presently, the cases of COVID-19 are tremendously increasing across the globe. It is noteworthy that collective efforts of public, government, HCPs along with AHPs can taper the condition [24]. Until now, none of the studies have exclusively focused AHPs' knowledge and attitude about COVID-19. Only few studies have assessed the knowledge and attitude regarding COVID 19 of DHCPs, and HCPs along with AHPs [3, 25-29]. Thus, a direct comparison cannot be made. Although, relevant questions and segment of previous studies dealing with AHPs has been discussed and compared in the present study.
The AHPs in the current study demonstrated a moderate knowledge (52.8\%) and good attitude $(80 \%)$ towards the COVID-19. An interesting finding in the present study is that the AHPs rely more on the $\mathrm{MOH}$ website $(80.5 \%)$ compared to other sources such as social media. It is contrary to the findings of studies done with Vietnam and Pakistan HCPs $[25,29]$ where social media was the most preferred source of information. Although social media helps in fast propagation of information but it has a potential to spread news which is otherwise not correct [30]. Hence, a closed watch with logic is must to follow the norms propagated with social media. In our study majority of the respondent referred $\mathrm{MOH}$ 
Table 2

Descriptive analysis of questions pertaining to the knowledge domain

\begin{tabular}{|c|c|c|c|c|}
\hline \multirow[t]{2}{*}{ Category of information } & \multirow[t]{2}{*}{ Question } & \multicolumn{3}{|c|}{ Response $f(\%)$} \\
\hline & & Yes & No & I don't know \\
\hline \multirow{2}{*}{$\begin{array}{l}\text { Nomenclature/Identification } \\
\text { of causative organism }\end{array}$} & ${ }^{*}$ COVID-19 is known as SARSCoV-2. & $72(36.9)$ & $72(36.9)$ & $51(26.2)$ \\
\hline & $\begin{array}{l}\text { Coronavirus is the causative organism responsible for Middle } \\
\text { East respiratory syndrome (MERS), severe acute respiratory syndrome } \\
\text { (SARS) and coronavirus disease } 2019 \text { (COVID-19). }\end{array}$ & $144(73.8)$ & $23(11.8)$ & $28(14.4)$ \\
\hline \multirow[t]{3}{*}{ Origin of infection } & In COVID-19, the Chinese horseshoe bats are the most probable origin. & $127(65.1)$ & $23(11.8)$ & $45(23.1)$ \\
\hline & *The main source of COVID-19 is a plant. & $2(1)$ & $168(86.2)$ & $25(12.8)$ \\
\hline & Does COVID-19 have any intermediate host? & $81(41.5)$ & $44(22.6)$ & $70(35.9)$ \\
\hline \multirow[t]{2}{*}{ Transmission } & COVID-19 is transmitted by close contact with an infected person or animal. & $164(84.1)$ & $24(12.3)$ & $7(3.6)$ \\
\hline & COVID-19 can be transmitted from respiratory droplets and contact. & $190(97.4)$ & $1(0.5)$ & $4(21)$. \\
\hline \multirow[t]{2}{*}{ Symptoms of infection } & The incubation time for the virus is $1-14$ days. & $192(98.5)$ & $2(1)$ & $1(0.5)$ \\
\hline & Fever, dry cough, and shortness of breath are the hallmark symptoms of COVID-19. & $193(99)$ & $1(0.5)$ & $1(0.5)$ \\
\hline High-risk group & $\begin{array}{l}\text { People with co-morbidity (Diabetes Mellitus and other chronic diseases) } \\
\text { are more likely to be infected with COVID-19. }\end{array}$ & $152(77.9)$ & $31(15.9)$ & $12(6.2)$ \\
\hline Prognosis & COVID-19 has a lower fatality rate than MERS-CoV. & $114(58.5)$ & $42(21.5)$ & $39(20)$ \\
\hline Investigation & PCR can be used to diagnose COVID- 19. & $143(73.3)$ & $9(4.6)$ & $43(22.1)$ \\
\hline Treatment & ${ }^{*}$ Antibiotics are the first line of treatment. & $33(16.9)$ & $128(65.6)$ & $34(17.4)$ \\
\hline \multirow[t]{2}{*}{ Prevention } & $\begin{array}{l}\text { *As per the guidelines issued from the health authorities, washing hands } \\
\text { with soap and water for at least } 30 \text { seconds can help prevent COVID- } 19 \text {. }\end{array}$ & $177(90.8)$ & $16(8.2)$ & $2(1)$ \\
\hline & *Vaccination of COVID-19 is available in the market. & $6(3.1)$ & $179(91.8)$ & $10(5.1)$ \\
\hline Total knowledge score & & $\begin{array}{c}\text { Poor } \\
28(14.4)\end{array}$ & $\begin{array}{l}\text { Moderate } \\
103(52.8)\end{array}$ & $\begin{array}{c}\text { Good } \\
64(32.8)\end{array}$ \\
\hline
\end{tabular}

Note: ${ }^{*}$ Negatively worded question 
Table 3

Descriptive analysis of questions pertaining to the attitude domain

\begin{tabular}{|c|c|c|c|c|c|c|}
\hline \multirow{2}{*}{$\begin{array}{l}\text { Category of } \\
\text { information } \\
\end{array}$} & \multirow[t]{2}{*}{ Question } & \multicolumn{5}{|c|}{ Response $\mathrm{n}(\%)$} \\
\hline & & SD & $\overline{\mathbf{D}}$ & $\mathbf{N}$ & $\mathbf{A}$ & $\mathbf{S A}$ \\
\hline \multirow[t]{2}{*}{$\begin{array}{l}\text { Awareness } \\
\text { about COVID-19 }\end{array}$} & $\begin{array}{l}\text { Health care professionals must acknowledge themselves } \\
\text { with all the information about COVID-19. }\end{array}$ & $8(4.1)$ & $1(0.5)$ & $7(3.6)$ & $52(26.7)$ & $127(65.1)$ \\
\hline & $\begin{array}{l}\text { Any related information about COVID- } 19 \text { should be } \\
\text { disseminated among peers and other health care workers. }\end{array}$ & $7(3.6)$ & $2(1)$ & $15(7.7)$ & $64(32.8)$ & $107(54.9)$ \\
\hline Precipitating factor & $\begin{array}{l}\text { To comply with any local restrictions on travel, movement } \\
\text { or large gatherings is one of the important ways of prevention. }\end{array}$ & $4(2.1)$ & $1(0.5)$ & $3(1.5)$ & $26(13.3)$ & $161(82.6)$ \\
\hline Symptoms & People with fever, cough and difficulty breathing should seek medical attention. & $6(3.1)$ & $1(0.5)$ & $5(2.6)$ & $37(19)$ & $146(74.9)$ \\
\hline \multirow[t]{7}{*}{$\begin{array}{l}\text { Infection } \\
\text { control protocol }\end{array}$} & $\begin{array}{l}\text { Prevalence of COVID-19 can be reduced by active participation } \\
\text { of health care workers in a hospital infection control program. }\end{array}$ & $4(2.1)$ & $10(5.1)$ & $17(8.7)$ & $75(38.5)$ & $89(45.6)$ \\
\hline & $\begin{array}{l}\text { Transmission of COVID- } 19 \text { infection can be prevented using } \\
\text { universal precautions given by CDC and WHO. }\end{array}$ & $5(2.6)$ & $4(2.1)$ & $12(6.2)$ & $64(32.8)$ & $110(56.4)$ \\
\hline & *Using N95 masks by undiagnosed patients is critically important. & $14(7.2)$ & $30(15.4)$ & $26(13.3)$ & $59(30.3)$ & $66(33.8)$ \\
\hline & Gowns, gloves, mask, and goggles must be used when dealing with COVID-19 patients. & $3(1.5)$ & 0 & $3(1.5)$ & $30(15.4)$ & $159(81.5)$ \\
\hline & $\begin{array}{l}\text { *Especially during the outbreak of COVID- } 19 \text {, every patient coming to the hospital } \\
\text { should be considered as infectious and all standard protocols should be adopted. }\end{array}$ & $6(3.1)$ & $10(5.1)$ & $9(4.6)$ & $46(23.6)$ & $124(63.6)$ \\
\hline & $\begin{array}{l}\text { Notify the receiving area about the patient's diagnosis and necessary precautions } \\
\text { should be taken as soon as possible before the patient's arrival. }\end{array}$ & $3(1.5)$ & 0 & $7(3.6)$ & $46(23.6)$ & $139(71.3)$ \\
\hline & $\begin{array}{l}\text { Health care professionals who transport patients should wear appropriate personal } \\
\text { protective equipment and perform hand hygiene afterwards. }\end{array}$ & $4(2.1)$ & $3(1.5)$ & $2(1)$ & $25(12.8)$ & $161(82.6)$ \\
\hline Prevention & It is important to stay more than 1 meter ( 3 feet) away from a person who is sick. & $5(2.6)$ & $4(2.1)$ & $4(2.1)$ & $42(21.5)$ & $140(71.8)$ \\
\hline \multirow[t]{2}{*}{ Treatment } & Only suspected cases of COVID-19 patients should be kept in isolation. & $8(4.1)$ & $16(8.2)$ & $17(8.7)$ & $42(21.5)$ & $112(57.4)$ \\
\hline & Intensive and emergency treatment should be given to diagnosed patients. & $4(2.1)$ & $7(3.6)$ & $22(11.3)$ & 48 (24.6) & $114(58.5)$ \\
\hline Total attitude score & & $\begin{array}{c}\text { Poor } \\
4(2.1)\end{array}$ & $\begin{array}{c}\text { Moderate } \\
35(17.9)\end{array}$ & & $\begin{array}{c}\text { Good } \\
156(80)\end{array}$ & \\
\hline
\end{tabular}

Note: SD - Strongly disagree, D - Disagree, N - Neutral, A - Agree, SA - Strongly agree. * Negatively worded question. 
Table 4

Frequency distribution of knowledge and attitude scores among the independent variables

\begin{tabular}{|c|c|c|c|c|c|c|c|c|c|}
\hline \multirow[t]{2}{*}{ Parameters } & \multicolumn{3}{|c|}{ Knowledge } & \multirow{2}{*}{$\begin{array}{c}\text { Total } \\
\mathrm{N}=195\end{array}$} & \multirow[t]{2}{*}{$P$-value $¥$} & \multicolumn{2}{|c|}{ Attitude } & \multirow{2}{*}{$\begin{array}{c}\text { Total } \\
\mathrm{N}=195\end{array}$} & \multirow[t]{2}{*}{$P$-value ${ }^{¥}$} \\
\hline & $\begin{array}{l}\text { Good } \\
n=64\end{array}$ & $\begin{array}{c}\text { Moderate } \\
n=103\end{array}$ & $\begin{array}{c}\text { Poor } \\
n=28\end{array}$ & & & $\begin{array}{c}\text { Good } \\
n=156\end{array}$ & $\begin{array}{c}\text { Moderate } \\
n=39\end{array}$ & & \\
\hline \multicolumn{10}{|l|}{ Nationality } \\
\hline Saudi & $48(31.8)$ & $79(52.3)$ & $24(15.9)$ & 151 & \multirow[t]{2}{*}{0.510} & $128(84.8)$ & $23(15.2)$ & 151 & \multirow[t]{2}{*}{$0.002^{* *}$} \\
\hline Non-Saudi & $16(36.4)$ & $24(54.5)$ & $4(9.1)$ & 44 & & $28(63.6)$ & $16(36.4)$ & 44 & \\
\hline \multicolumn{10}{|l|}{ Gender } \\
\hline Male & $50(37.3)$ & $67(50)$ & $17(12.7)$ & 134 & \multirow[t]{2}{*}{0.128} & $109(81.3)$ & $25(18.7)$ & 134 & \multirow[t]{2}{*}{0.487} \\
\hline Female & $14(23)$ & $36(59)$ & 11(18) & 61 & & $47(77)$ & $14(23)$ & 61 & \\
\hline \multicolumn{10}{|l|}{ Age } \\
\hline $20-30$ years & $19(33.3)$ & $26(45.6)$ & $12(21.1)$ & 57 & \multirow[t]{4}{*}{0.115} & $45(78.9)$ & $12(21.1)$ & 57 & \multirow[t]{4}{*}{0.166} \\
\hline $31-40$ years & $31(31.6)$ & $52(53.1)$ & $15(15.3)$ & 98 & & $80(81.6)$ & $18(18.4)$ & 98 & \\
\hline $41-50$ years & $12(37.5)$ & $20(62.5)$ & $0(0)$ & 32 & & $27(84.4)$ & $5(15.6)$ & 32 & \\
\hline $51-60$ years & $2(25)$ & $5(62.5)$ & $1(12.5)$ & 8 & & $4(50)$ & $4(50)$ & 8 & \\
\hline \multicolumn{10}{|l|}{ Educational level } \\
\hline Intern & $7(41.2)$ & $6(35.3)$ & $4(23.5)$ & 17 & \multirow[t]{5}{*}{0.278} & $14(82.4)$ & $3(17.6)$ & 17 & \multirow[t]{5}{*}{0.844} \\
\hline Diploma & $10(29.4)$ & $19(55.9)$ & $5(14.7)$ & 34 & & $28(82.4)$ & $6(17.6)$ & 34 & \\
\hline Bachelor & $28(30.4)$ & $49(53.3)$ & $15(16.3)$ & 92 & & $75(81.5)$ & $17(18.5)$ & 92 & \\
\hline Master & $9(26.5)$ & $21(61.8)$ & $4(11.8)$ & 34 & & $26(76.5)$ & $8(23.5)$ & 34 & \\
\hline Doctorate/PhD & $10(55.6)$ & $8(44.4)$ & $0(0)$ & 18 & & $13(72.2)$ & $5(27.8)$ & 18 & \\
\hline \multicolumn{10}{|l|}{ Region you work in } \\
\hline Central region & $12(30)$ & $22(55)$ & $6(15)$ & 40 & \multirow[t]{5}{*}{0.818} & $35(87.5)$ & $5(12.5)$ & 40 & \multirow[t]{5}{*}{0.105} \\
\hline Eastern region & $1(10)$ & $8(80)$ & $1(10)$ & 10 & & $7(70)$ & $3(30)$ & 10 & \\
\hline Western region & $16(38.1)$ & $21(50)$ & $5(11.9)$ & 42 & & $28(66.7)$ & $14(33.3)$ & 42 & \\
\hline Northern region & $24(35.3)$ & $33(48.5)$ & $11(16.2)$ & 68 & & $56(82.4)$ & $12(17.6)$ & 68 & \\
\hline Southern region & $11(31.4)$ & $19(54.3)$ & $5(14.3)$ & 35 & & $30(85.7)$ & $5(14.3)$ & 35 & \\
\hline \multicolumn{10}{|l|}{ Organization setup } \\
\hline Government & $52(31.5)$ & $92(55.8)$ & $21(12.7)$ & 165 & \multirow[t]{2}{*}{0.117} & $137(83)$ & $28(17)$ & 165 & \multirow[t]{2}{*}{$0.013^{*}$} \\
\hline Private & $12(40)$ & $11(36.7)$ & $7(23.3)$ & 30 & & $19(63.3)$ & $11(36.7)$ & 30 & \\
\hline \multicolumn{10}{|l|}{ Work experience } \\
\hline $1-3$ years & $20(34.5)$ & $26(44.8)$ & $12(20.7)$ & 58 & 0.643 & $44(75.9)$ & $14(24.1)$ & 58 & 0.634 \\
\hline $4-6$ years & $11(32.4)$ & $19(55.9)$ & $4(11.8)$ & 34 & & $28(82.4)$ & $6(17.6)$ & 34 & \\
\hline $7-10$ years & $12(35.3)$ & $17(50)$ & $5(14.7)$ & 34 & & $26(76.5)$ & $8(23.5)$ & 34 & \\
\hline More than 10 years & $21(30.4)$ & $41(59.4)$ & $7(10.1)$ & 69 & & $58(84.1)$ & $11(15.9)$ & 69 & \\
\hline Source of knowledge & & & & & & & & & \\
\hline Only one source & $31(30.1)$ & $48(46.6)$ & $24(23.3)$ & 103 & $<0.001$ & $78(75.7)$ & $25(24.3)$ & 103 & 0.115 \\
\hline More than one source & $33(35.9)$ & $55(59.8)$ & $4(4.3)$ & 92 & & $78(84.8)$ & $14(15.2)$ & 92 & \\
\hline
\end{tabular}

$¥$ Chi-Square test; ${ }^{\complement}$ Fisher’s exact test; ${ }^{*} P<0.05$; ${ }^{* *} P<0.01$.

Table 5

Multivariate logistic analysis to assess factors associated with moderate/poor attitude

\begin{tabular}{lcccc}
\hline Parameters & Odds & \multicolumn{2}{c}{$95 \%$ CI } & $P$-value \\
\cline { 3 - 4 } & ratio & Lower & Upper & \\
\hline $\begin{array}{l}\text { Nationality } \\
\text { Saudi }\end{array}$ & Ref & & & \\
$\begin{array}{l}\text { Non-Saudi } \\
\text { Organization setup }\end{array}$ & 3.171 & 1.465 & 6.866 & $0.003^{* *}$ \\
$\begin{array}{l}\text { Government } \\
\text { Private }\end{array}$ & $\begin{array}{c}\text { Ref } \\
\text { Priven }\end{array}$ & & & \\
\hline
\end{tabular}

Note: CI - Confidence interval; ${ }^{*} P<0.05 ;{ }^{* *} P<0.01$; Ref - Reference category.

website for information which shows a unanimous spread of information throughout the country. This dissemination of information by $\mathrm{MOH}$ was not only restricted to the HCWs, but also the general public was being constantly informed through the website and awareness campaigns [31].

In the knowledge domain, pertaining to the questions related to nomenclature and origin of the disease, respondent have correctly answered the question in majority of the cases. Incorrect responses were received for question related to the virus and disease identification pertaining to SARS CoV-2 and COVID-19 respectively. The probable reason could be the constant update in the taxonomy based on the evidences gathered by researches in this field. On January 122020 WHO named the virus novel coronavirus 2019 (2019-nCoV) [9]. Later, the name of the virus was renamed to severe acute respiratory syndrome coronavirus 2 (SARS CoV-2) in a consensus statement of the International Committee on Taxonomy of Viruses [32]. On February 11 2020, 
to avoid any inaccuracy and stigma, the disease was named coronavirus disease 2019 (COVID-19) [9]. Therefore, it seems logical that the AHPs might have been confused with the nomenclature and have responded incorrectly. Questions pertaining route of transmission were correctly answered by most of the respondents. The main route of disease transmission is supposed to be through respiratory droplets via direct or contact transmission [12], although with emerging evidences fecal-oral, saliva, aerosols as well as airborne and fomite transmissions are gaining attention $[12,13]$. The aerosols measuring $<5$ microns remain disseminated especially in the closed environment with improper ventilation for a longer period of time, hence are supposed to be more infectious in the medical setup [11]. The knowledge of AHPs about the route of transmission for COVID-19 was consistent with other studies [26-28, 33]. Questions about the symptoms and recognizing patients at higher risk, has shown excellent correct response rate of $99 \%$. Another study carried out with Egyptian population had a response rate of $95 \%$, which is comparable [28]. This is considerably important for AHPs to be updated with the knowledge about this aspect as it will help them to screen the patients as well as plan the treatment accordingly. The common symptoms associated with COVID-19 include fever, cough, shortness of breath, myalgia, headache, vomiting and diarrhoea $[9,10]$. It has been reported that elder age group and patients with systemic illness are more prone for COVID-19 [10, 34]. In a study done on Saudi Arabian population, it was found that the patient affected by COVID-19 has shown clinical manifestation of fever (85.6\%), cough (89.4\%), and sore throat $(81.6 \%)$. The other symptoms were runny nose ( $72 \%)$, myalgia (28.6\%), headache (27.3\%), and gastrointestinal symptoms (14.3\%) [35]. In the same study $20.1 \%$ of the patient who had co-morbidity were affected by COVID-19 [35]. As far as questions related to prognosis and treatment were concerned, the case fatality rate of COVID-19 is lower than SARS and MERS [15] and it was correctly answered by majority of the respondents. Regarding the antibiotics been the first line of treatment, was answered correctly. As a matter of fact, it is a viral infection and antibiotics can play a role only to prevent bacterial superinfections. Presently, many antiviral drugs, plasma therapy, and corticosteroids are given as symptomatic treatment [36]. Knowing the causative agent as virus, many antiviral drug therapies have been proposed but to conclude affirmatively as a curative agent, none of them have claimed as the pro- phylactic/curative antiviral drug [37]. The AHPs have responded correctly to the availability of the vaccines. Vaccines for COVID-19 are currently not available on the market, although in many countries vaccines are under the phase III trial, i.e. human trial are ongoing, whereas in Russia the vaccine has been registered although the trial is still ongoing [38]. For the prevention of disease transmission, WHO and centre of disease control (CDC) guidelines have identified the practice of hand hygiene of outmost importance [39, 40]. The knowledge of AHPs regarding the question about duration of performing hand hygiene is not adequate. According to WHO, it should be at done for least 40 second with soap and water when the hands are visibly soiled. The technique adopted for this is equally important as it includes five specific movements ensuring that every aspect of hand is disinfected [39-41]. When visible dirt is not seen, the hand rub technique can be followed for 20 seconds with 60\%-80\% alcohol-based hand sanitizer $[39,40]$. Thus, the time duration needs to be emphasized to the AHPs. An important finding for this present study is that none of the independent variables such as age, gender, region, education, educational level and years of experience have affected the knowledge outcome. The knowledge level of AHPs about COVID 19 was similar all around KSA.

The AHPs have attained a good $(80 \%)$ attitude scores towards COVID-19 which portrays that they are fighting the disease with a positive attitude. Display of such attitude is must to overcome any disease. It has been reported that person with positive attitude and positive behaviors have a better tendency for coping strategies [42]. Attitude score of the present study were similar to few [28] and less compared with the study done on Nepalese HCPs [27].

It is noteworthy that AHPs are well aware that they should attain knowledge about the COVID-19 and disseminate among peers so that they should remain updated with the current norms. It shows zeal among them to combat the disease with updated knowledge. The AHPs are well aware about the protocol of travel restriction and large gathering. As per the WHO, the patients are supposed to be in quarantine for about 14 days if they had travelled internationally or locally or they have come in close contact to the COVID-19 positive patient [43]. As far as the large gathering is concerned, the protocol of safe distancing is compromised leading to spread of the disease. Hence, recommendations and advisory were published not to gather in a crowded area [43, 44]. Interestingly, the AHPs have shown a good attitude towards the 
infection control protocol. The results were similar with other countries [25] and better than few others [27]. Few questions related to infection control has been overestimated and overrated by the AHPs such as the usage of $\mathrm{N} 95$ respirators by undiagnosed patients of COVID-19. Over usage of respirators or other personal protective equipment (PPEs) can lead to shortage and hence it cannot be provided to the needy [45]. Hence, judicious usage of mask is a crucial. Although, as per the new evidence of airborne transmission, WHO advised to wear a mask, perform social distancing and follow hand hygiene measure to curb the disease spread [46]. The AHPs are well aware that they have to follow the infection control protocol and guidelines issued by WHO, CDC as well as local body i.e. MOH. Strict compliance with the measures will help in complete rehabilitation of the patient and lessen the chance of AHPs from getting infected. As reported in a study in Saudi Arabia, $12.5 \%$ of COVID-19 patients were working in a health care facility [35]. Hence, it is important to understand that the HCPs along with AHPs are at higher risk of getting this disease. Any disparity to follow infection control protocol can lead to grave consequences for the health care machinery. Regarding treatment, the AHPs are well-aware about the criteria for a patient to be advised for isolation or admit in intensive care unit. This shows a positive attitude and correct approach for the treatment. An important point to be addressed is the attitude of AHPs working in a private setup, as they were shown to have 2.8 times risk for possessing a moderate/poor attitude in comparison to AHPs working in a governmental setup. However, the level of knowledge of AHPs working in both the sets up was similar. In a study done on Saudi Arabian hospitals, it was found that there is a significant association between attitudes towards healthcare service quality and hospital performance [47].

The present study has a few limitations. Since the study was conducted online in a period where the country was facing lockdown, a face-to-face survey would have excluded the potential bias of misinformation. In the background of the current survey results, continuing professional development program (CPD) can be conducted to bridge the gap between existing and the required knowledge. Based on these findings, a recommendation can be made which would be helpful for the AHPs to work with a scientific background by protecting the patients as well as themselves.

\section{Conclusions}

The allied healthcare professionals have shown moderate knowledge and good attitude towards $\mathrm{CO}$ VID-19. The knowledge of the AHPs can be enhanced by conducting continuing professional development program. Furthermore, strategic planning should be implemented for the private hospitals to enhance the attitude of AHPs.

\section{Author contributions}

Conceptualization, D.S., A.A.A, K.C.S. and M.G. S; methodology, D.S., A.A.A, K.C.S. and M.G.S; software, K.C.S. and A.F.S.; validation, K.C.S., D.S. and A.F.S.; M.K.A formal analysis, K.C.S.; investigation, K.C.S., K.A and A.F.S.; resources, A.A.A, K.C.S. and M.G.S; data curation, D.S; K.C.S. and M.G.S; writing — original draft preparation, D.S. and K.C.S.; writing-review and editing, D.S., A.A.A, K.C.S., A.F.S., K.A., M.G.S;M.K.A visualization, K.C.S., A.A.A, and M.G.S; supervision, K.C.S; project administration, M.G.S;M.K.A funding acquisition, A.A.A. All authors have read and agreed to the publish the final version of the manuscript.

\section{Conflict of interest}

The authors declare no conflict of interest.

\section{Funding}

This research received no external funding.

\section{References}

[1] Guan WJ, Ni ZY, Hu Y, Liang WH, Ou CQ, He JX, Liu L, Shan H, Lei CL, Hui DS, Du B. Clinical characteristics of coronavirus disease 2019 in China. New England Journal of Medicine. 2020;382(18):1708-20.

[2] Draper H, Wilson S, Ives J, Gratus C, Greenfield S, Parry J, Petts J, Sorell T. Healthcare workers' attitudes towards working during pandemic influenza: a multi method study. BMC Public Health. 2008;8(1):192.

[3] Olum R, Chekwech G, Wekha G, Nassozi DR, Bongomin F. Coronavirus Disease-2019: Knowledge, Attitude, and Practices of Health Care Workers at Makerere University Teaching Hospitals, Uganda. Frontiers in Public Health. 2020;8:181. 
[4] What is Allied Health? ASAHP. https://www.asahp.org/ what-is. Accessed on 21 August 2020.

[5] Heiwe S, Kajermo KN, Tyni-Lenné R, Guidetti S, Samuelsson M, Andersson IL, Wengström Y. Evidence-based practice: attitudes, knowledge and behaviour among allied health care professionals. International Journal for Quality in Health Care. 2011;23(2):198-209.

[6] Lizarondo L, Kumar S, Hyde L, Skidmore D. Allied health assistants and what they do: a systematic review of the literature. Journal of Multidisciplinary Healthcare. 2010;3:143.

[7] Talaee N, Varahram M, Jamaati H, Salimi A, Attarchi M. Stress and burnout in health care workers during COVID19 pandemic: validation of a questionnaire. Zeitschrift Fur Gesundheitswissenschaften. 2020 Jun 11:1.

[8] Cucinotta D, Vanelli M. WHO declares COVID-19 a pandemic. Acta bio-medica: AteneiParmensis. 2020;91(1):15760.

[9] Guo YR, Cao QD, Hong ZS, Tan YY, Chen SD, Jin HJ, Tan KS, Wang DY, Yan Y. The origin, transmission and clinical therapies on coronavirus disease 2019 (COVID19) outbreak-an update on the status. Military Medical Research. 2020;7(1):1-0.

[10] Meng L, Hua F, Bian Z. Coronavirus disease 2019 (COVID-19): emerging and future challenges for dental and oral medicine. Journal of Dental Research. 2020;99(5): 481-7.

[11] A AS, Srivastava KC, Shrivastava D, Hosni HA, Khan ZA, Al-Johani K, Alzoubi IA, B S, Sghaireen MG, Alam MK. Recommendations, Practices and Infrastructural Model for the Dental Radiology Set-up in Clinical and Academic Institutions in the COVID-19 Era. Biology. 2020;9:334.

[12] Peng X, Xu X, Li Y, Cheng L, Zhou X, Ren B. Transmission routes of 2019-nCoV and controls in dental practice. International Journal of Oral Science. 2020;12(1):1-6.

[13] Galbadage T, Peterson BM, Gunasekera RS. Does COVID19 Spread Through Droplets Alone?. Frontiers in Public Health. 2020;8:163.

[14] Van Doremalen N, Bushmaker T, Morris DH, Holbrook MG, Gamble A, Williamson BN, Tamin A, Harcourt JL, Thornburg NJ, Gerber SI, Lloyd-Smith JO. Aerosol and surface stability of SARS-CoV-2 as compared with SARS-CoV-1. New England Journal of Medicine. 2020; 382(16):1564-7.

[15] Mahase E. Coronavirus: covid-19 has killed more people than SARS and MERS combined, despite lower case fatality rate.

[16] Barry M, Al Amri M, Memish ZA. COVID-19 in the Shadows of MERS-CoV in the Kingdom of Saudi Arabia. Journal of Epidemiology and Global Health. 2020;10(1):1-3.

[17] https://www.moh.gov.sa/en/Ministry/MediaCenter/Public ations/Pages/covid19.aspxAccessed on 17th august 2020

[18] https://www.moh.gov.sa/Ministry/MediaCenter/Publicati ons/Documents/Coronavirus-Disease-2019-Guidelinesv1.2.pdf:Accessed on 21 August 2020

[19] https://www.moh.gov.sa/Ministry/MediaCenter/Publicat ions/Documents/Physiotherapy-Recommendations.pdf. Accessed on 21 August 2020.

[20] Handu D, Moloney L, Rozga M, Cheng FW. Malnutrition Care During the COVID-19 Pandemic: Considerations for Registered Dietitian Nutritionists. Journal of the Academy of Nutrition and Dietetics. 2020 May 14.

[21] Zhong BL, Luo W, Li HM, Zhang QQ, Liu XG, Li WT, Li Y. Knowledge, attitudes, and practices towards COVID19 among Chinese residents during the rapid rise period of the COVID-19 outbreak: a quick online cross-sectional survey. International Journal of Biological Sciences. 2020;16(10): 1745 .

[22] Asaad AM, El-Sokkary RH, Alzamanan MA, El-Shafei M. Knowledge and attitudes towards Middle East respiratory syndrome-coronavirus (MERS-CoV) among health care workers in south-western Saudi Arabia. East Mediterr Health J. 2019;25.

[23] Seid MA, Hussen MS. Knowledge and attitude towards antimicrobial resistance among final year undergraduate paramedical students at University of Gondar, Ethiopia. BMC Infectious Diseases. 2018;18(1):312.

[24] Al-Hanawi MK, Angawi K, Alshareef N, Qattan AM, Helmy HZ, Abudawood Y, Alqurashi M, Kattan WM, Kadasah NA, Chirwa GC, Alsharqi O. Knowledge, Attitude and Practice Toward COVID-19 Among the Public in the Kingdom of Saudi Arabia: A Cross-Sectional Study. Frontiers in Public Health. 2020;8.

[25] Huynh G, Nguyen TN, Vo KN, Pham LA. Knowledge and attitude toward COVID-19 among healthcare workers at District 2 Hospital, Ho Chi Minh City. Asian Pacific Journal of Tropical Medicine. 2020;13(6):260.

[26] Zhou M, Tang F, Wang Y, Nie H, Zhang L, You G, Zhang M. Knowledge, attitude and practice regarding COVID-19 among health care workers in Henan, China. Journal of Hospital Infection. 2020 Apr 9.

[27] Nepal R, Sapkota K, Adhikari K, Paudel P, Adhikari B, Paudyal N, Sapkota K, Nepal R. Knowledge, attitude and practice regarding COVID-19 among healthcare workers in Chitwan, Nepal.

[28] Abdel Wahed WY, Hefzy EM, Ahmed MI, et al. Assessment of Knowledge, Attitudes, and Perception of Health Care Workers Regarding COVID-19, A Cross-Sectional Study from Egypt. J Community Health (2020). https:// doi.org/10.1007/s10900-020-00882-0

[29] Saqlain M, Munir MM, Rehman SU, Gulzar A, Naz S, Ahmed Z, Tahir AH, Mashhood M. Knowledge, attitude, practice and perceived barriers among healthcare workers regarding COVID-19: a cross-sectional survey from Pakistan. Journal of Hospital Infection. 2020;105(3): 419-23.

[30] Kumar Chandan Srivastava, Deepti Shrivastava, Kumar Gaurav Chhabra, Waqar Naqvi, Arti Sahu. Facade of media and social media during COVID-19: A review. ijrps [Internet]. 2020Jun.19 [cited 2020Aug.18];11(SPL1):1429. Available from: https://pharmascope.org/ijrps/article/ view/2288

[31] Alshammary F, Siddiqui AA, Amin J, Ilyas M, Rathore HA, Hassan I, Alam MK, Kamal MA. Prevention Knowledge and Its Practice Towards COVID-19 Among General Population of Saudi Arabia: A Gender-based Perspective. Current pharmaceutical design. 2020.

[32] of the International CS. The species Severe acute respiratory syndrome-related coronavirus: classifying 2019-nCoV and naming it SARS-CoV-2. Nature Microbiology. 2020;5(4):536.

[33] Alduraywish AA, Srivastava KC, Shrivastava D, Sghaireen MG, Alsharari AF, Al-Johani K, Alam MK. A Countrywide Survey in Saudi Arabia Regarding the Knowledge and Attitude of Health Care Professionals about Coronavirus Disease (COVID-19). Int J Environ Res Public Health. 2020;17:7415.

[34] Siddiqui AA, Alshammary F, Amin J, Rathore HA, Hassan I, Ilyas M, Khursheed Alam M. Knowledge and practice regarding prevention of COVID-19 among the Saudi Arabian population. Work.(Preprint):1-9. 
[35] Alsofayan YM, Althunayyan SM, Khan AA, Hakawi AM, Assiri AM. Clinical characteristics of COVID-19 in Saudi Arabia: A national retrospective study. Journal of Infection and Public Health. 2020 Jun 8.

[36] Tobaiqy M, Qashqary M, Al-Dahery S, Mujallad A, Hershan AA, Kamal MA, Helmi N. Therapeutic Management of COVID-19 Patients: A systematic review. Infection Prevention in Practice. 2020:100061.

[37] YAVUZ S, Ünal S. Antiviral treatment of COVID-19. Turkish Journal of Medical Sciences. 2020;50(SI-1):611-9.

[38] Covid-19: Russia approves vaccine without large scale testing or published resultsBMJ 2020; 370 doi: https://doi.org/ 10.1136/bmj.m3205 (Published 13 August 2020)Cite this as: BMJ 2020;370:m3205

[39] World Health Organization. interim recommendations on obligatory hand hygiene against transmission of COVID19. https://www.who.int/publications/m/item/interim-reco mmendations-on-obligatory-hand-hygiene-against-transm ission-of-covid-19. Accessed on 21 August 2020.

[40] World Health Organization. Infection prevention and control during health care when novel coronavirus (nCoV) infection is suspected Interim guidance, 19 March 2020.

[41] Hillier MD. Using effective hand hygiene practice to prevent and control infection. Nurs Stand. 2020;35(5):45-50.
[42] McEachan R, Taylor N, Harrison R, Lawton R, Gardner P, Conner M. Meta-analysis of the reasoned action approach (RAA) to understanding health behaviors. Annals of Behavioral Medicine. 2016;50(4):592-612.

[43] World Health Organization. Considerations for quarantine of individuals in the context of containment for coronavirus disease ((COVID-19): interim guidance, 19 March 2020. World Health Organization; 2020.

[44] Centers for Disease Control and Prevention. Considerations for Events and Gatherings. https://www.cdc.gov/coronavi rus/2019-ncov/community/large-events/considerationsfor-events-gatherings.html, Accessed on 21 August 2020.

[45] Mahmood SU, Crimbly F, Khan S, Choudry E, Mehwish S. Strategies for Rational Use of Personal Protective Equipment (PPE) Among Healthcare Providers During the COVID-19 Crisis. Cureus. 2020;12(5).

[46] World Health Organization. Advice on the use of masks in the context of COVID-19: interim guidance, 5 June 2020. World Health Organization; 2020.

[47] Alsharari YS, bin Aziz FS, Taib CA, Yusoff RZ. The Impact of Attitudes towards Healthcare Service Quality on Organisational Performance: Evidence from the Saudi Arabia. Research in Business and Management. 2017;5(1):1. 